\begin{tabular}{|c|c|c|}
\hline & JHE 5 (2) (2020) 66-71 & $=$ \\
\hline & Journal of Health Education & \\
\hline $\begin{array}{l}\text { Journal of } \\
\text { HealthEducation }\end{array}$ & http://journal.unnes.ac.id/sju/index.php/jhealthedu & \\
\hline
\end{tabular}

\title{
Knowledge of Personal Hygiene among Undergraduates
}

\author{
Akorede Seun Nurudeen $^{1 \bowtie}$, Atanda Toyin ${ }^{2}$ \\ DOI: http://dx.doi.org/10.15294/jhe.v5i2.38383
}

${ }^{1}$ Ahmadu Bello University, Nigeria

${ }^{2}$ University of Ilorin, Nigeria

\section{History Article}

Submitted 20 April 2020

Revised 16 August 2020

Accepted 27 September 2020

\section{Keywords}

hygiene; knowledge; personal hygiene; undergraduates

\begin{abstract}
Background: Personal hygiene is the act of taking care of oneself, it is also referring to as an act of maintaining the cleanliness of one's body and clothing to improve overall health and well-being. The purpose of the study was to examine if undergraduates know about personal hygiene, investigate if undergraduates of University of Ilorin differ in personal hygiene knowledge based on age, and assess if there is a difference in knowledge of personal hygiene among undergraduates of University of Ilorin based on gender.

Method: A descriptive research design of using surveys was employed for this study. Multi-stage sampling techniques of simple random, proportionate, and convenient sampling techniques were used to select 398 respondents for the study. The researcher developed a questionnaire validated by three experts from the Department of Health Promotion and Environmental Health Education, University of Ilorin was used for the study. ANOVA and Independent t-test was used to test the hypotheses. All hypotheses were tested at 0.05 level of significance.

Results: The findings from this study revealed that undergraduates of University of Ilorin know about personal hygiene. The mean values of Yes (330/ 82.9\%) is greater than the mean value of No $(68 / 17.8 \%)$. There is a significant difference in knowledge of personal hygiene among undergraduates of University of Ilorin based on age $(p=0.023)$. There is a significant difference in knowledge of personal hygiene among undergraduates of University of Ilorin based on gender $(p=0.018)$.

Conclusion: The study concluded that undergraduates of University of Ilorin know about personal hygiene.
\end{abstract}

\section{How to Cite}

Nurudeen, A. S., \& Toyin, A. (2020). Knowledge of Personal Hygiene among Undergraduates. JHE (Journal of Health Education), 5(2), 66-71.
${ }^{\bowtie}$ Corresponding Author:

Samaru Campus, Zaria, Kaduna State, Nigeria

E-mail: akorede.sn@unilorin.edu.ng
p-ISSN 2527-4252

e-ISSN 2528-2905 


\section{INTRODUCTION}

Personal hygiene can be defined as the practice of maintaining cleanliness and promoting and preserving body health (Al-Rifaai, et al., 2018). Personal hygiene is the act of taking care of oneself, it also refers to as act of maintaining cleanliness of one's body and clothing to improve overall health and well-being. Taking care of body parts such as hair, eyes, nose, mouth, teeth, skin, armpit among others is refers to as personal hygiene. Hygiene is a very personal subject, and encouraging changes in hygiene requires skill and care (Tamiru et al., 2017). Good knowledge of personal hygiene goes in a long way to improve students' health and prevent diseases. However a lot can be done personally to ensure that we remain in good health by practicing good personal hygiene and keeping the environment safe from disease causing organisms (Odigwe, 2015). The present inadequate knowledge base hinders the development of improved strategies for enhancing the maintenance of personal hygiene, which is of great importance to decrease the burden of communicable diseases in the developing countries (Khatoon, et al., 2017).

In developing and underdeveloped countries around the world which do not have sufficient modern technology and resources to combat epidemic, education on good personal hygiene will serve a major role in minimizing the risk of outbreak of infectious diseases (Odigwe, 2015). Hygiene is an old concept related to medicine, as well as to personal and professional care practices (Odonkor, et al., 2019). Hygiene refers to practices associated with ensuring good health and cleanliness. Hygiene is defined as any application made and any sanitary precaution taken to be protected from environments that can damage our health. Hygiene is the study and practice of preventing illness or stopping it from spreading, by keeping things clean. The concept also refers to the set of practices associated with the preservation of health and healthy living. It is a concept related to medicine as well as to personal, professional care and practices affecting most aspects of living; although it is most often associated with disease preventive measures. The foundations of lifelong responsibility for the maintenance of personal hygiene are laid down in childhood, which is important for a healthy childhood, for a healthy adulthood, and for the development of positive values about health and the use of health services (Khatoon et al., 2017).

Students' personal hygiene are shaped by variety of determinants including the practice modeled by family members and peers as well as those portrayed in the media and educational system (Tailor, et al., 2010). The exercise of proper personal hygiene is one of the essential parts of our daily life. Personal hygiene is the practice of maintaining cleanliness of one's own body. Good hygienic care as well as knowledge in terms of personal hygiene contributes to a large extent on factors relating to healthful living and prevention of hazards from diseases. These health risk factors are directly related to some important daily activities implicated with worthy operational actions and obligatory responsibilities, such as washing hands before meals and after defecation with soap, brushing teeth at least twice a day specially after breakfast and after meals, taking bath with soap regularly, keeping nails short and taking regular exercise (Ali, et al., 2013).

All human beings, irrespective of age, gender, level of education or religious affiliation require good personal hygiene to live a healthy life (Thomas, 2012). Primary and secondary school days are best time to learn healthful habits and practice the. This is because as the children grow older, these habits become permanent. During adolescence period, there are changes in the physical body such as growth of pubic hair and body hair in female, the start of periods (menarche). As these changes occur, it means that their personal hygiene will need to improve positively too. Good personal hygiene entails washing the hands frequently especially after using the toilet or touching possibly contaminated items, bathing regularly, being careful not to cough or sneeze on others, putting tissue and items containing body fluids into the bin after use, washing clothes regularly especially under wears and using protection (such as gloves) when you are at the risk of catching an infection (Odigwe, 2015).

Personal hygiene is a concept that is commonly used in medical and public health practices. It involves maintaining the cleanliness of our body and clothes. It is personal (Bastos, 2010). It is defined as a condition promoting sanitary practices to self. The knowledge of personal hygiene is vital in all our everyday activities. The public health purposes of personal hygiene include the prevention of faeco-orally transmitted diseases, aesthetic values and social impact. Sometimes one may be quick to associate an illness to the influence of external factors and other causes. Personal hygiene cannot be over emphasized in ensuring good health and total well-being (Aiello \& Larson, 2012).

In a study of knowledge and practices of personal hygiene among senior secondary school 
students of Ambassadors College, Ile-Ife, Nigeria, the result shows that $270(97.8 \%)$ of the respondents had heard of the term 'personal hygiene'. School constituted the largest source of information about personal hygiene accounting for $46 \%$ of responses. Parents accounted for $43.5 \%$ followed by books $17.4 \%$, friends, churches and mosques constituted the least accounting for $12.7 \%$ and $13 \%$ respectively. More than $95 \%$ of respondents responded true to personal hygiene as practices performed by individual to care for ones bodily health and well being through cleanliness (Ilesanmi, 2016). The author further reported that all the respondents responded true to personal hygiene includes cleanliness of the body and clothes. $99 \%$ of respondents responded true to personal hygiene includes regular brushing and flossing of teeth. $98 \%$ of respondents responded true to personal hygiene includes regular and proper hand washing. $88 \%$ of respondents agreed that personal hygiene includes balanced rest and exercise. About $80 \%$ and $77 \%$ responded true to seeing a doctor and dentist respectively as part of personal hygiene. The percentage of knowledge of respondents about personal hygiene products is $98.7 \%$. The percentage of knowledge of respondents about disease or condition which could be caused or worsened by poor personal hygiene is $63.2 \%$.

Women having better knowledge regarding personal hygiene because of menstruation. $\mathrm{He}$ further concluded that age has influence on knowledge of personal hygiene among secondary school students the author investigated (Benson, 2011). School is place which not only provides education to children but also learning environment (Khatoon et al., 2017). Evidence showed that schools maintained the important role of caring for students' health, which included policy environment and stakeholder engagement, health education sessions, and practical health promotion activities (Susanto, et al., 2016). It was based on this that the researcher investigated the knowledge of personal hygiene among undergraduates of University of Ilorin, Kwara State, Nigeria.

\section{METHODS}

Descriptive research design of survey type was used in this study. The population for this study comprised all the undergraduate students of University of Ilorin, Nigeria with 43,983 students spread across the fifteen faculties in the University (Unilorin General Academic Office, 2018).

Multi-stage sampling technique consisting of simple random, proportionate and convenient sampling techniques was use to select the sample size of 398 undergraduates in the following selected faculty who serve as respondents for this study. ANOVA and Independent t-test were used to test the hypotheses. All hypotheses were tested at 0.05 level of significance.

\section{RESULTS AND DISCUSSIONS}

Table 1 shows the mean values of respondents that pick Yes was 330 (82.9\%) which is greater than the mean value of respondents that pick No $68(17.8 \%)$. Therefore, this shows that undergraduates of University of Ilorin know about personal hygiene.

Table 1. Undergraduates of University of Ilorin Knowledge of Personal Hygiene

\begin{tabular}{|c|c|c|}
\hline Items & Yes & No \\
\hline $\begin{array}{l}\text { Personal hygiene is about } \\
\text { body cleanliness. }\end{array}$ & $\begin{array}{l}324 \\
(81.4 \%)\end{array}$ & $\begin{array}{l}74 \\
(18.6 \%)\end{array}$ \\
\hline $\begin{array}{l}\text { Keeping my nails trimmed } \\
\text { and clean is part of per- } \\
\text { sonal hygiene }\end{array}$ & $\begin{array}{l}346 \\
(86.9 \%)\end{array}$ & $\begin{array}{l}52 \\
(13.1 \%)\end{array}$ \\
\hline $\begin{array}{l}\text { Washing my hair regularly } \\
\text { is part of personal hygiene }\end{array}$ & $\begin{array}{l}324 \\
(81.4 \%)\end{array}$ & $\begin{array}{l}74 \\
(18.6 \%)\end{array}$ \\
\hline $\begin{array}{l}\text { Keeping the hair well- } \\
\text { trimmed is part of personal } \\
\text { hygiene }\end{array}$ & $\begin{array}{l}330 \\
(82.9 \%)\end{array}$ & $\begin{array}{l}68 \\
(17.1 \%)\end{array}$ \\
\hline $\begin{array}{l}\text { Picking my teeth with } \\
\text { broom stick is not healthy } \\
\text { for my teeth }\end{array}$ & $\begin{array}{l}328 \\
(82.4 \%)\end{array}$ & $\begin{array}{l}70 \\
(70.6 \%)\end{array}$ \\
\hline $\begin{array}{l}\text { Cleaning my teeth with } \\
\text { tooth paste and brush pre- } \\
\text { vent tooth decay }\end{array}$ & $\begin{array}{l}324 \\
(81.4 \%)\end{array}$ & $\begin{array}{l}74 \\
(18.4 \%)\end{array}$ \\
\hline $\begin{array}{l}\text { Washing my hands after } \\
\text { using toilet is part of per- } \\
\text { sonal hygiene }\end{array}$ & $\begin{array}{l}344 \\
(86.4 \%)\end{array}$ & $\begin{array}{l}54 \\
(13.6 \%)\end{array}$ \\
\hline $\begin{array}{l}\text { Washing my cloth regularly } \\
\text { prevent skin diseases }\end{array}$ & $\begin{array}{l}336 \\
(84.4 \%)\end{array}$ & $\begin{array}{l}62 \\
(15.6 \%)\end{array}$ \\
\hline $\begin{array}{l}\text { Taking my bath every day } \\
\text { is part of personal hygiene }\end{array}$ & $\begin{array}{l}320 \\
(82.9 \%)\end{array}$ & $\begin{array}{l}68 \\
(17.1 \%)\end{array}$ \\
\hline $\begin{array}{l}\text { Washing my hand before } \\
\text { and after eating is part } \\
\text { personal hygiene }\end{array}$ & $\begin{array}{l}324 \\
(81.4 \%)\end{array}$ & $\begin{array}{l}74 \\
(18.6 \%)\end{array}$ \\
\hline$X$ & $\begin{array}{l}330 \\
(82.9)\end{array}$ & $\begin{array}{l}68 \\
(17.8)\end{array}$ \\
\hline
\end{tabular}

This result implies that undergraduates of University of Ilorin know about personal hygiene. This is support of findings of Ilesanmi (2016) who found out in his study on knowledge and practices of personal hygiene among senior secondary 
school students of Ambassadors College, Ile- Ife, Nigeria that $270(97.8 \%)$ of the respondents had heard of the term 'personal hygiene'. School constituted the largest source of information about personal hygiene accounting for $46 \%$ of responses. Parents accounted for $43.5 \%$ followed by books $17.4 \%$. Friends, Churches and Mosques constituted the least accounting for $12.7 \%$ and $13 \%$ respectively. More than $95 \%$ of respondents responded true to personal hygiene as practices performed by individual to care for ones bodily health and well being through cleanliness.

All the respondents responded true to personal hygiene includes cleanliness of the body and clothes. $99 \%$ of respondents responded true to personal hygiene includes regular brushing and flossing of teeth. $98 \%$ of respondents responded true to personal hygiene includes regular and proper hand washing. $88 \%$ of respondents agreed that personal hygiene includes balanced rest and exercise. About $80 \%$ and $77 \%$ responded true to seeing a doctor and dentist respectively as part of personal hygiene. The percentage of knowledge of respondents about personal hygiene products is $98.7 \%$. The percentage of knowledge of respondents about disease or condition which could be caused or worsened by poor personal hygiene is $63.2 \%$.

In previous study more than $90 \%$ students had knowledge about body and clothes hygiene, about teeth brushing, about regular clothes washing, $87.9 \%$ had knowledge about soap use in personal hygiene, $46.3 \%$ had knowledge about use of toilet paper, $72.6 \%$ had knowledge about use of nail cutter and $29.8 \%$ knowledge about sanitary pad (Shekhawat, et al., 2019).

University students represent a population uniquely situated to benefit from hygiene interventions (Miko et al., 2012). Knowledge and awareness on water handling and hand washing are important predisposing factor to influence hygiene behaviour and students observing considerable gap of positive hygiene behavior (Mulubirhan \& Abera, 2014). Das showed in their study, 96 reported that they are aware of hand hygiene practices, but $3 / 4$ th of them said that they had no formal training on the same (Das, et al., 2015).

Another findings said that a difference in hygiene behaviour outcome was statistically significant with knowledge status of the students on water handling issues $(\mathrm{P}<0.001)$ and hand washing matters $(\mathrm{P}<0.05)$ (Mulubirhan \& Abera, 2014). Campaigns aimed at (1) establishing and sustaining social norms of good personal hygiene and (2) educating students on the biolo- gic mechanisms by which handwashing prevents disease could be most useful to increase safe hygiene practices (Miko et al., 2012).

As college students transition into independent adulthood, they are likely to develop a foundation of personal behaviors that may persist for decades to come (Miko et al., 2012). Regarding practice, bathing \& brushing teeth every day, hand washing before and after meal, hand washing after using toilet, hand washing after handling garbage, hand washing after handling animal, regular hair cutting and using soap as hygiene product were found good while practice of regular nail cutting, using of facial tissue and cotton swab as hygiene product were not satisfactory (Shekhawat et al., 2019).

Table 2. Analysis of variance on difference on knowledge of personal hygiene among undergraduates of University of Ilorin based on age

\begin{tabular}{llllll}
\hline Model & $\begin{array}{l}\text { Sum of } \\
\text { squares }\end{array}$ & $\begin{array}{l}\text { Mean } \\
\text { square }\end{array}$ & DF & F & $\begin{array}{l}\text { p- } \\
\text { value }\end{array}$ \\
\hline $\begin{array}{l}\text { Be- } \\
\text { tween }\end{array}$ & 31.451 & 15.72 & 2 & & \\
groups & & & & & \\
$\begin{array}{l}\text { Within } \\
\text { groups }\end{array}$ & 1624.77 & 4.11 & 395 & 3.823 & 0.023 \\
Total & 1656.221 & & 387 & & \\
\hline
\end{tabular}

Table 2 reveals that F-calculated value is 3.823 , and the p-calculated value is 0.023 , which is less than 0.05 level of significance. This implies that there is a significantly difference in knowledge of personal hygiene based on age undergraduate of University of Ilorin. The HSD Post Hoc test conducted reveals that there is difference between age group of 15-19 and 20-24 with mean difference of 0.66239 and significance of 0.021 .

This is in support with study of Mulubirhan (2014) who found in his research knowledge of students' was gauged and the proportion of positive hygiene behaviour among school children was fairly high in those who had adequate knowledge. Accordingly, knowledge is important factor to have observed positive hygiene behavior (Mulubirhan \& Abera, 2014).

Of note is that age contributed to personal hygiene in present study; children that are advanced in age had better personal hygiene (Ahmadu et al., 2013). This might be related to developmental adaptability of children as they increase in age. Ability to comprehend and apply basic personal hygiene tips would be improved in older compared with younger children (Ahmadu et al., 2013). 
Akorede Seun Nurudeen \& Atanda Toyin / Journal of Health Education 5 (2) (2020) 66-71

Table 3. Independent sample t-test statistics on knowledge of personal hygiene based on gender

\begin{tabular}{llccc}
\hline Group & $\mathrm{N}$ & Mean $(\mathrm{X})$ & Std. Deviation & Sig. \\
\hline Male & 152 & 18.46 & 1.94 & 0.018 \\
Female & 246 & 18.11 & 2.18 & \\
\hline
\end{tabular}

Table 3 shows that there is significant difference in knowledge of personal hygiene among undergraduates of University of Ilorin based on gender. This is in accordance with finding of Benson (2011) who found out that women having better knowledge regarding personal hygiene because of menstruation. Similiar findings study from Rajbhandari (2018) said that female students obtained significantly higher average knowledge score $(93.4 \%)$ than the male $(83.7 \%)$ regarding the knowledge of personal hygiene. This discrepancy in knowledge score could be due to variation in family orientation, socio-cultural differences and physiologically higher need for cleanliness among adolescent female (Rajbhandari, et al., 2018).

Hand hygiene compliance was higher in academic buildings than in the student recreation center, but visual prompts did not improve hand hygiene by gender or race/ethnicity, except in those students in the "other" ethnic group (Anderson \& Hanson, 2010). Thus, hand hygiene programs targeted at college students should be tailored to improve hand hygiene in Caucasian students (Anderson \& Hanson, 2010).

Consistent with previous research, men reported worse household hygiene habits compared with women (Miko et al., 2012). More women than men reported consistent hand washing before preparing food $(p=0.002)$ and after using the toilet ( $p=0.001)$ (Das et al., 2015). In contrast with study results from Akwenabuaye and Ine (2020) that there was no significant difference between gender and adoption of hygienic practices among residents in University of Calabar community $(p=0.55)$. Visual prompts in addition to educational campaigns may promote better hand hygiene compliance by improving awareness of its importance (Anderson \& Hanson, 2010).

\section{CONCLUSION}

Based on the findings of the study, it was concluded that undergraduates of University of Ilorin know about personal hygiene, there is a difference in the knowledge of personal hygiene among undergraduate of University of Ilorin based on age, and there is a difference in the knowledge of personal hygiene among undergradua- te of University of Ilorin based on gender.

\section{REFERENCES}

Ahmadu, B. U., Rimamchika, M., Ibrahim, A., Nnanubumom, A. A., Godiya, A., \& Emmanuel, P. (2013). State of personal hygiene among primary school children: A community based cohort study. Sudanese Journal of Paediatrics, 13(1), 38-42.

Aiello, A. E., \& Larson, E. L. (2002). What is the evidence for a causal link between hygiene and infections?. The Lancet infectious diseases, 2(2), 103-110.

Akwenabuaye, V., \& Ine, R. (2020). Gender and Consistent Hand Hygiene Adherence among Staff and Students of University of Calabar during the Ebola Outbreak in Nigeria. European Journal of Scientific Research, 156(2), 131-137.

Al-Rifaai, J. M., Al Haddad, A. M., \& Qasem, J. A. (2018). Personal Hygiene among College Students in Kuwait: A Health Promotion Perspective. Journal of Education and Health Promotion, $7(92)$.

Ali, M. Y., Rahman, M. M., \& Siddiqui, M. H. (2013). Exploring Degree of Awareness about Healthcare and Hygienic Practices in Secondary School Students Residing in Semi-Urban Areas of Bangladesh. Sudan Journal of Pediatric, 2(1), 55-62.

Anderson, D. R., \& Hanson, K. G. (2010). From blooming, buzzing confusion to media literacy: The early development of television viewing. Developmental Review, 30(2), 239-255.

Assefa, M., \& Kumie, A. (2014). Assessment of factors influencing hygiene behaviour among school children in Mereb-Leke District, Northern Ethiopia: a cross-sectional study. BMC Public Health, 14(1), 1000.

Bastos, T. S. (2010). Personal Hygiene, Knowledge, Attitude and Practice of Secondary School Students in Ikeja.

Benson, P. T. (2011). Assessing the Knowledge, Attitudes and Practices of Street Food Vendors in City of Johannesburg Regarding Food Hygiene and Safety School of Public Health, University of the Western Cape.

Das, D., Kumar-Mandal, A., Das, J., Sardar, S., \& Naskar, S. (2015). Practice of Personal Hygiene \& Morbidity Pattern among Medical Students of a Rural Medical College, West Bengal, India. IOSR Journal of Dental and Medical Sciences Ver. II, 14(5), 2279-2861.

Ilesanmi, O. T. (2016). Knowledge and Practices of Personal Hygiene among Senior Secondary School Students of Ambassadors College, IleIfe, Nigeria. Texila International Journal of Public Health, 4(4), 231-242.

Khatoon, R., Sachan, B., Khan, M., \& Srivastava, J. (2017). Impact of school health education program on personal hygiene among school children of Lucknow district. Journal of Family 
Medicine and Primary Care, 6(1), 97.

Miko, B. A., Cohen, B., Conway, L., Gilman, A. Seward, S. L., \& Larson, E. (2012). Determinants of personal and household hygiene among college students in New York City, 2011. American Journal of Infection Control, 40(10), 940-945.

Odigwe, O. (2015). Good Personal Hygiene: A Fight against the Spread of Infectious Diseases. MOJ Public Health, 2(2), 15406.

Odonkor, S. T., Kitcher, J., Okyere, M., \& Mahami, T. (2019). Self-Assessment of Hygiene Practices towards Predictive and Preventive Medicine Intervention: A Case Study of University Students in Ghana. BioMed Research International, 2019.

Rajbhandari, A. K., Dhaubanjar, R., GC, K. B., \& Dahal, M. (2018). Knowledge and practice of personal hygiene among secondary school students of grade nine and ten. Journal of Patan Academy of Health Sciences, 5(2), 107-113.

Shekhawat, R., Sodha, V. S., Sharma, N., \& Verma, M. (2019). Knowledge and practice regarding personal hygiene among students of government schools of Bikaner, Rajasthan. International Journal of Advanced Community Medicine, 2(2), 108-111.

Susanto, T., Sulistyorini, L., Wuryaningsih, E. W., \& Bahtiar, S. (2016). School health promotion: A cross-sectional study on Clean and Healthy Living Program Behavior (CHLB) among Islamic Boarding Schools in Indonesia. International Journal of Nursing Sciences, 3(3), 291-298.

Taylor, J. K., Basco, R., Zaied, A., \& Ward, C. (2010). Hand hygiene knowledge of college students. American Society for Clinical Laboratory Science, 23(2), 89-93.

Tamiru, D., Argaw, A., Gerbaba, M., Ayana, G., Nigussie, A., Jisha, H., \& Belachew, T. (2017). Enhancing Personal Hygiene Behavior and Competency of Elementary School Adolescents through Peer-Led Approach and SchoolFriendly: A Quasi-Experimental Study. Ethiopian Journal of Health Sciences, 27(3), 245-254.

Thomas, J. M. (2012). Food Microbiology: An Introduction (2nd.ed.). England: Academic press.

Unilorin General Academic Office. (2018). University of Ilorin Registrar Office. 